$$
\begin{aligned}
& \text { DEPARTHEN }
\end{aligned}
$$

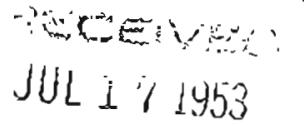

ITINERARY REPORT

TO:

FROM:

SUBJECT:

PhIl R. Holdsworth, Gomissioner of Mines

$$
\text { of Mines }
$$

M. W. Jesper. Assoctato Mining Engineer

Trip to Copper River vallev to check on mining ectivity in the region, and locate and tentatively arrange for horses for the proposed reconnalssance stiudy of the Nutzotin Mountains Iater in the Beason, the Iatter In vestigation having objective of determining whether structurgl and mineralfzation andits ong hold possibilities for ocourrences of important nickel-oopper deposits simflar to those now under intensive expojoration and development on the Yukon Territory side of the boundary.

$$
6 / x^{4},-6 / \times 6,19: 2
$$

Iune 2li: Laft the Alaska Aypaum Ouien Compeny amp at

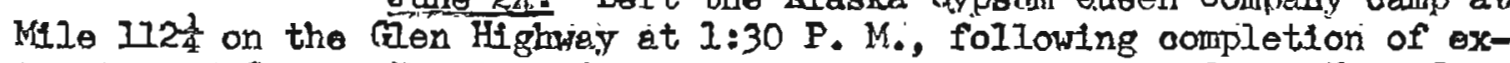
fination of Ceorge Fenndmore's oopper prospects on east alde of Iron Creak (or Yellow Jacket Creek). Sheep Mounte1n area.

At Fureke Roadhouse the looation for Pirst Milidogt" drill hole of the Alaska 011 and Developrent Campany, selected by thalr consulting petrolelm goologist, Mr. Thornberg, we.s polnted out; 1ts"location is approximately 1000 feet northweat of the highway. Th1s first hole is scheduled to be "spudded-in" by mid-Arugust.

The United States Geologloal Surver were stated to have a 4 or 5 man party in the hilla north of the highway, their project primarily designed as a correlation of the sedimentary etructures for oil and gas exploration. Iou Anderton is the proker, and is using all of his hirses Y... on this projeat.

George Ballinger was reported to be working on his "Discov-

$$
k x-76 \cdot 29
$$

ery" placer olatm with one man. This property ls loceted on Albert Croek, 8 tributary of Grooked Creek, the latter flowing into the Ifttio Nelchina Ríver.

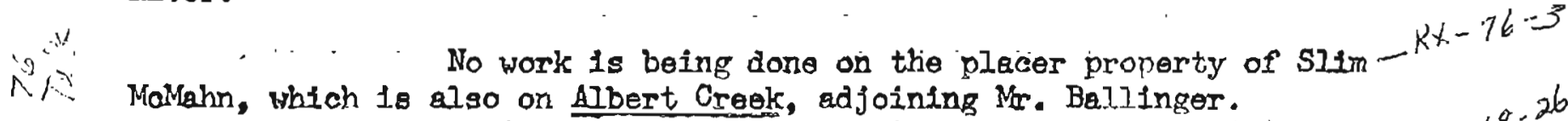
Glen Alien. Gien Allen. Inquiry was made at the Rood Comission of fioe, 1t was $k K$ near Paxon's, would be ready for fourth of Iuly use to Pangle Lalees - a distance of 10 miles.

Gekonia. Informition obtäned here Indicated Jacob Berry and Aesociater expocted to complete ef their track-mouited waghing plent and excovation equipment and expected to be operating latter part of season on placer property of Mtddle Fork Minling Company, located on the 
Middle Fork of the Gestoohina Hiver. This report has alnce been confirmed, with 5 men employed. No other work in placer area of the Chestoohina drainage besin has beensoported.

Chestoching: Ffort was made to conteat Harry Boyden without suocess. It was reported, however, that $M^{2}$. Boyden was not dartioularly jnterested In rentsl or use of his horses.

Knute Peterson was sald to be prospeoting this season on Trall Creek north of the Naberna Highway. This roed, recnnditioned where

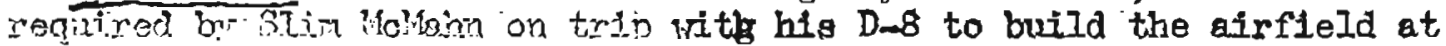
Orange H1Il, was reported to be in very good oondition.

Approahes were being built on east and west side of Chestoohina River for the new bridge planned for 1954. Contractors orews were busy at number" of sentiona betwein cakone and Chestochina graveling. the highway and reilaing the roadbed oeveral feet in plaoes.

The night was spent at Chestochina.

Juar 25. Loft Chestochina at 8 A. M.

Copper Center. TIms was spent at Mining Recorders office going over.. the records. Only one recent Notice of Iooation of Lode Claim was recorded. $1 . x-68.23$ This is recorded in Vol. 74, Pege 300. the loeation war made by prospector Kiotor Manvilie June 13, 1953, and flled for reoord on June 22, 1953, wtth John S. Hellerthel and J. C. Hern as Hitresses. The discovery and lo. cation was limited to ono oloim, and is described at follows:-

"Sever miles from the junction of the Cantwell road with the Richardson Highway".

This is doubtless looated in and to north of the Tengle Lakes aree and is a oopner showing whioh Mir. Manvilile discussed with me in May 1953. At that time he reported hoving spent part of the last two seasong ('5I and '52) in effort to trace large "float", oontaining fairly highgrade bornite and chalcopyrite, to 1ts souroe. At thet, time he steted ho was refiurning there this season to make a"last efrort", mich apparently was successful.

The second recording of intereat was a leed of Mining Clairas betiveen Martin F. Radovin and Delano Mining Company, whtoh read. $k x-81-1$ ronghly as foltors:-

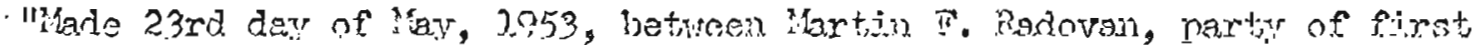

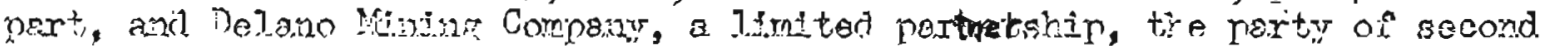
nort, has ryansferet to party of serond pert. the folloning mining claims:"Triessic. No.s I to 13 (looated April 1929 through to August 1032), Triasiste No.s 30 to 32 (located in Appla Aupust 1931 and August 1948), Aupiste located in July 10,48 , Booto in 1948 (also July), Ki..Ki locoted in Angust 394i3, Pongo Boy located In 194,8, considting of one contiguons group of approximstely 400 acres.

"The foregoing" ninexal clglms are siturted slong or nesr Glacier Creak, Chitistone Mining District, in Chitina Recording District, Conner Centers, Mlackes. 
Miring Recorder (and J. S. Coundastionerfor the Distriot) Carl Tdin "believes"the tis oooperotitig and following prodedure carried in. ainendients pasied by the Territorial Ingiglature this year. However, tiznt Is questionable due to his lack of trairing, proper interpretetion, and belief the compensation is not sufficient where individual flling for

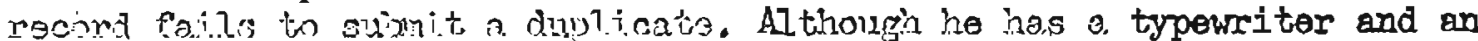
amatuer "hunt \& and pecker" typist should be able to knock out a counj.e averape Notices of Location or Pronfs of Iabor or Deags, he complatned that it was necessary for him to "farm out" that work and pay 2.00 for an hours work in copying a couple of documents. Itr. "din vas "enoouragied" and advised to contact our Department on eny questions that might arise.

Chitina. - Contiming toward Valdez in aftemonn, roads crews did not

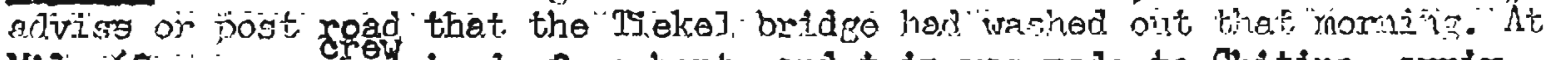
Mile 62 a surrey advised of wahout, and trip was made to Chitina, arrivIng there at 6 P. M.

That evening and following mornting 0 . A. Nelsön, Frank Carroll, and Nós. Jean Richaris gave Information oovering limited mining cotivities in the MoCerthy district. This confined to following:-

\section{(Gracier Creelc)}

Ghtak NeIson oopper property. Diamoind drilling progrem

was started whth Th. OMEl as oonsultant, but work susponded due to sudden 1IJnegs of the diamond arill operator who was flown out to hospltal.

Radivan oopper property. The Delene Mining Company awerd- 8 $^{-1}$ ed a 400 foot tunnel contract in late Kay or early June. It was roported that 200 feet rimained to complete the contract.

J. B. N'NAel, Dan Creek plecer. Welter Molnes with one $-87-3$ man is dolng the assessment work on this ground.

There f.s no gotfvity on Chittitu Croek.

Claus Wilhelm is watchman at the Konnicott property.

Creek.

Charkes Jacobsen was reported to be propeoting on Young unfavorable oomment.

Activities of Viotor Rbintie are causing a great deal of

June 26: Pllot Filile of Cordova Aimays was contacted.

Based at ChItina, he provides service for the Copper Rlver region and Shushenne Distriat, with a 3-place Plper. He reñorted that N. P Nelson, Harivy Sutherland, Al Wright, and Um. James and wife were only ones he bew to be in the Shushanne diatriot. Plane service to the latter area fs on or about the lst. 5th. 3nth, 15th, 20th, and 25th of each month, and the fare is 323.00 each wav. 
Pllot Haille elso advised ho was servicing the Kenrioott exploretion party at Orange Hill. Mr. Glen Reed is the company enpineer in charge, and a crew of 4 is employed. A portable gasoline powered fackhomer is betng used for aurface open-out work, and geophysical equipment bas been flown in.

It was interesting to note that on questioning Frank Carroll regariling the Chitina population, ho stated that an actual coint last Christmas showdr 210 people were residing in and near the tow.

closed until June 29th.

Ieft: Chftina at $10: 30 \mathrm{~A}$. M. The Valdez Hitghay remained

Copper Conter. Controted Pllot smoke Thomes, who operates a 3-place P1per plane, and is based at Slane, teking out hunting parties and others.

Pilot Thomes advised he is familiar with the Nutzotin Mountain and Shushenna region, and has frequently landod on various river bars. It 1s suggested that if the study of that area ia made this seasm that "servloj.ng" of the party by means of a gmell plane be considored.

P1lot, Thomas also advised he hed fust returied from trip Into the Chisne rfier (Chestoahtne district) where he relocated the open Blacer ground along that atream.

Returned to Anchorage at 8:30 P. M. on June 26th.

Last woek SIIn líchahn advised that Louia EJmex had reloo- $b^{8} 1^{2}$ ated the opon ground on Slate Creek July Ist, 1953.

Anchorage, Aleaka

JuIy 13, 1953
Respectfully submitted,

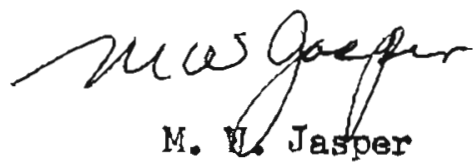

Assooiate Mining Engineer 


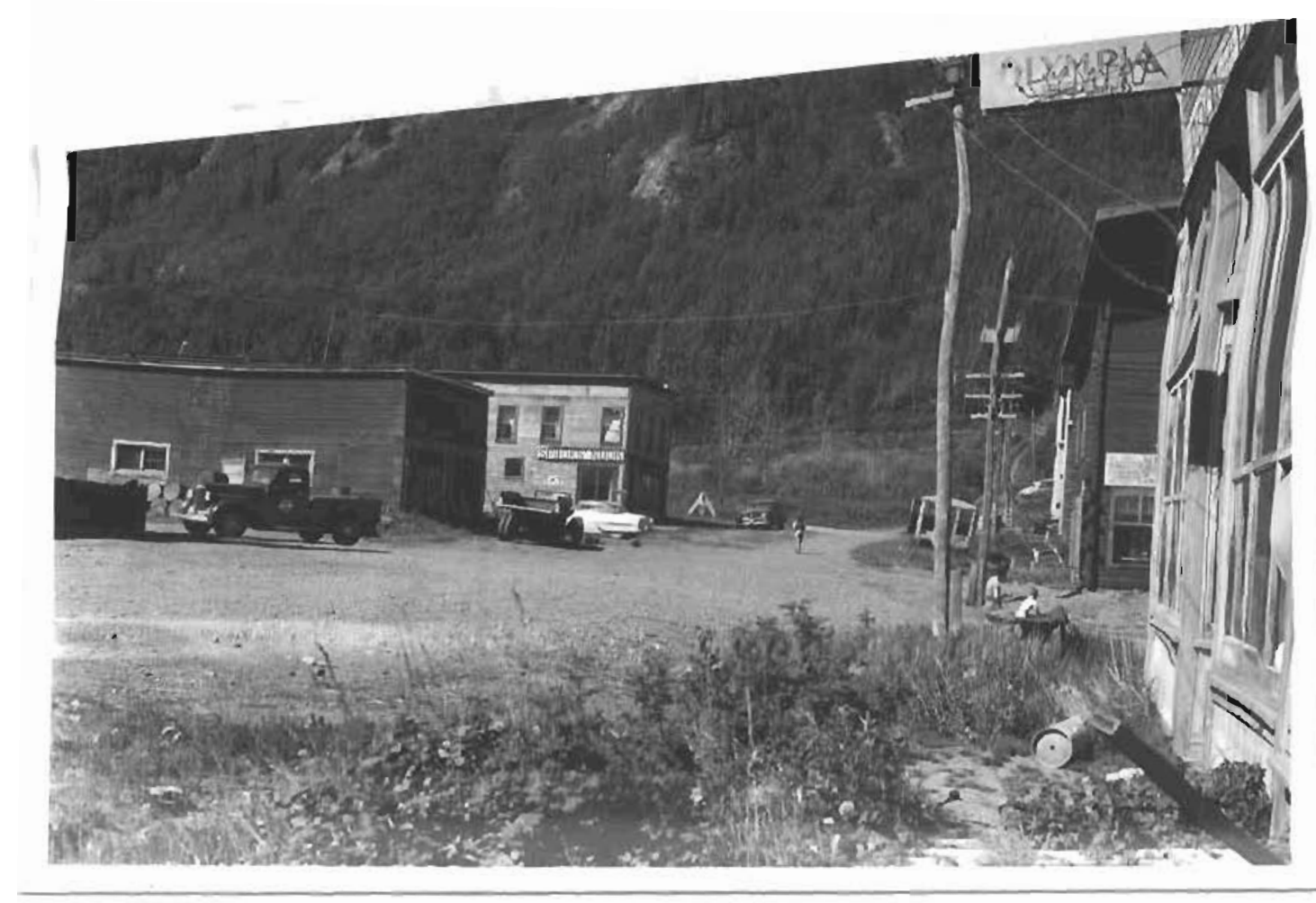

June 26, 2953

Chitine business district.

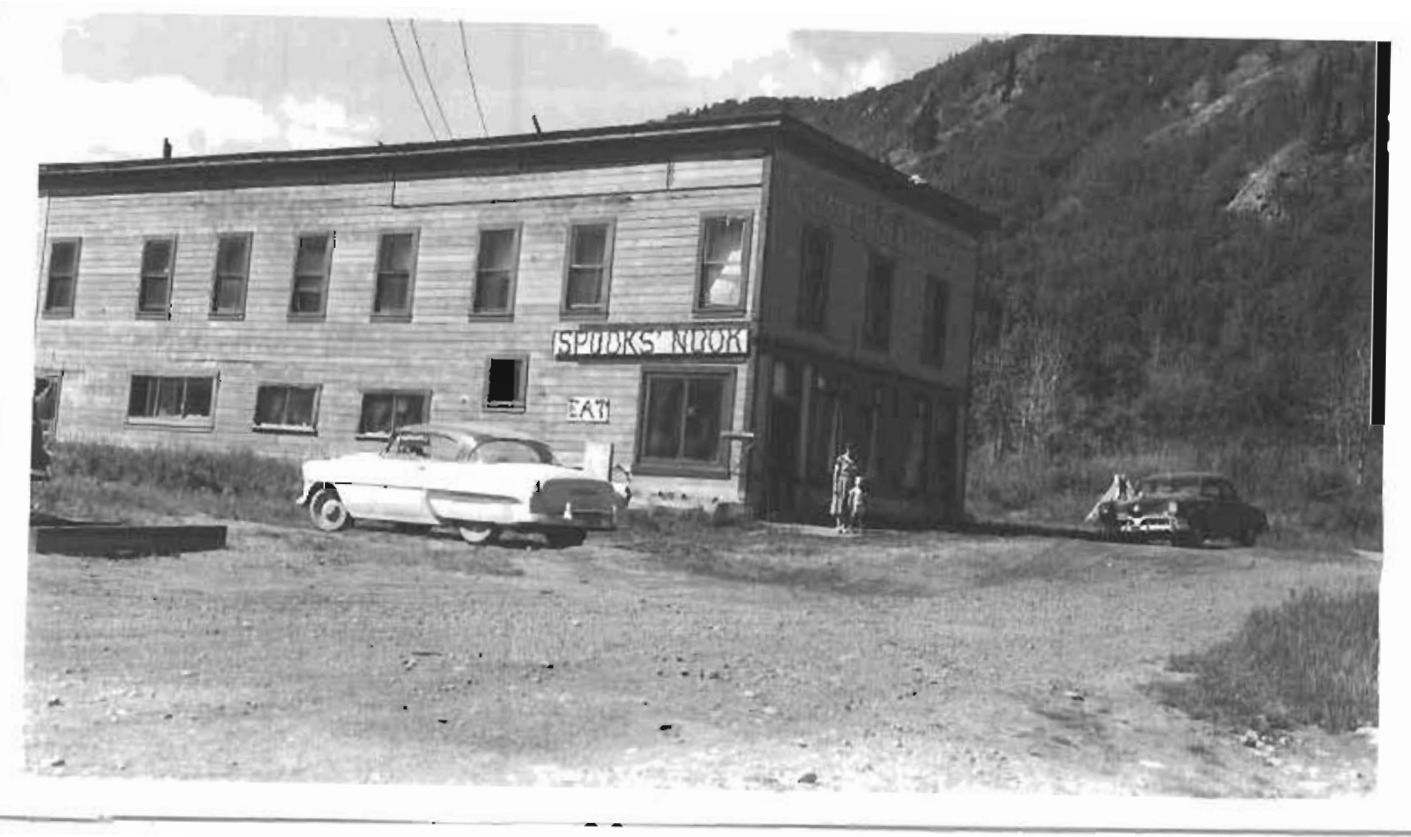

PLATE I 


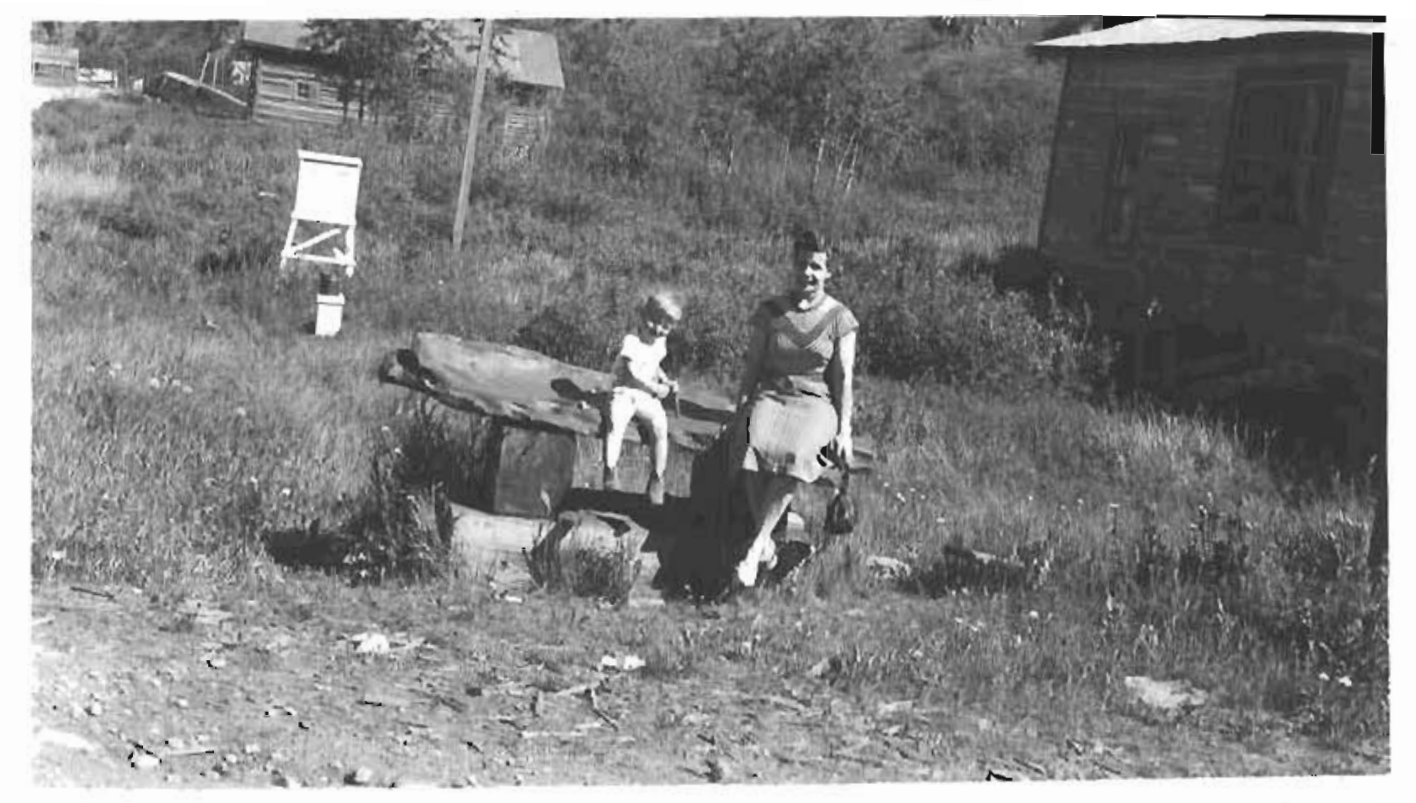

June 26, 1953

Coftina. $2400 \mathrm{lb}$ slab of native oopper

"Qreeter" on highway
to Ghost Town of
Ohitina

\section{(a)}

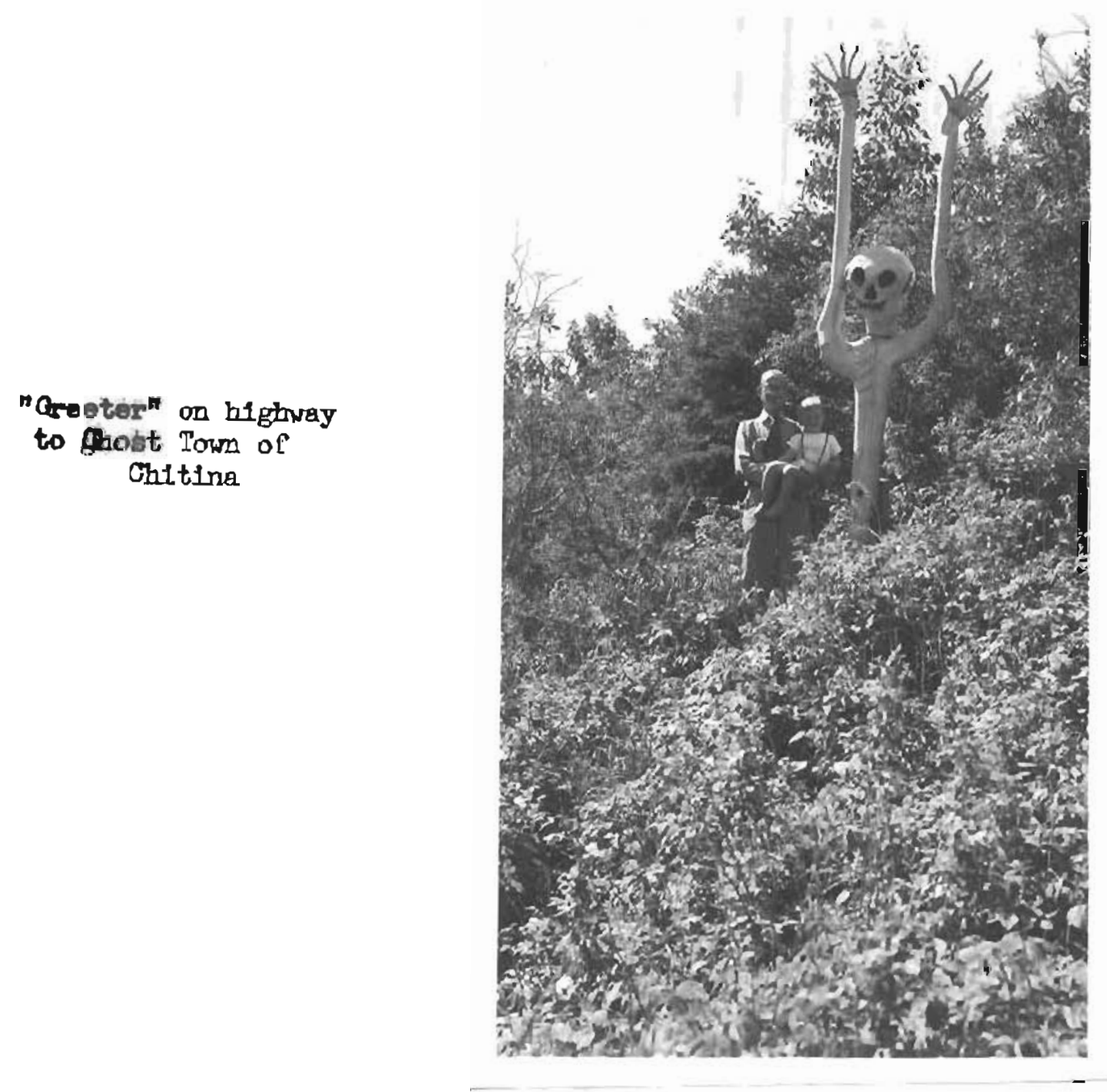




\section{June 26. 1953}

Chitina aporoach to the old Copper River railway bridge

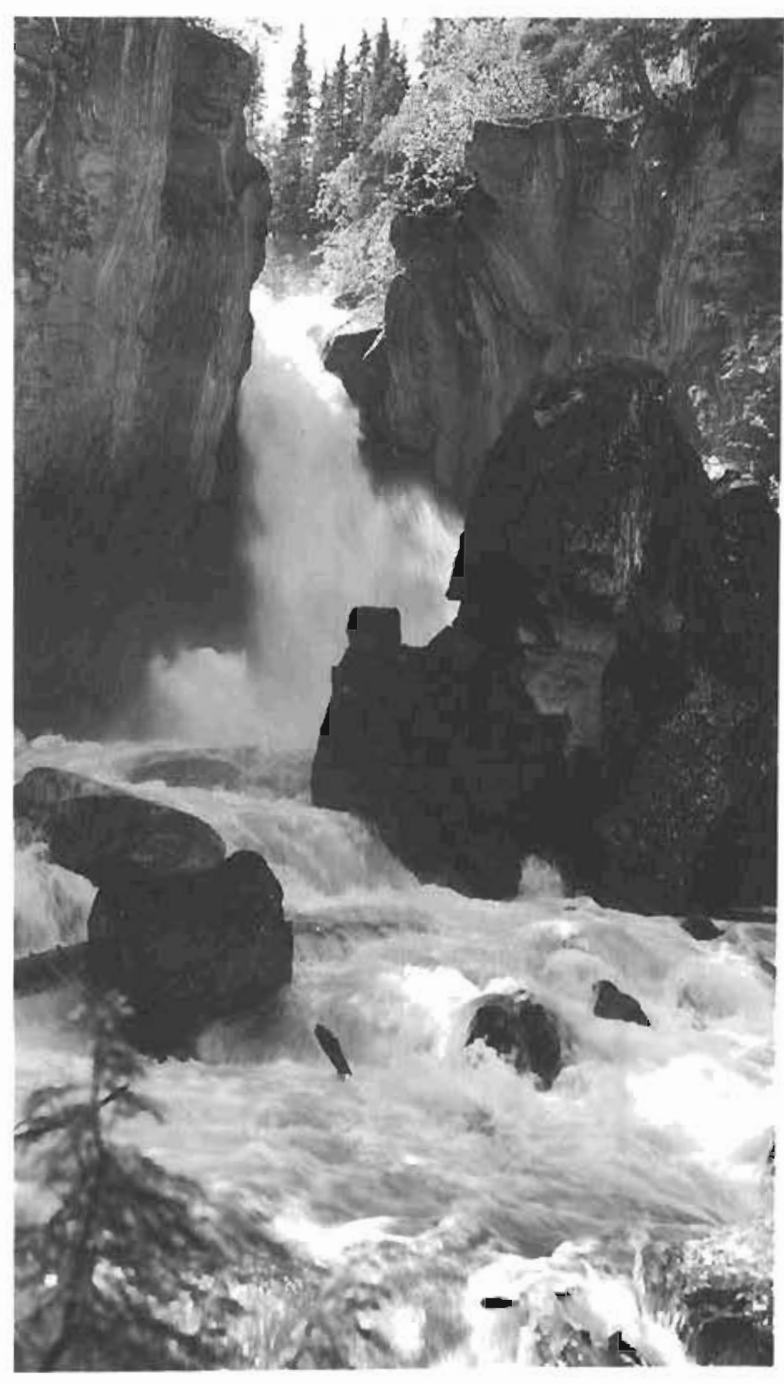

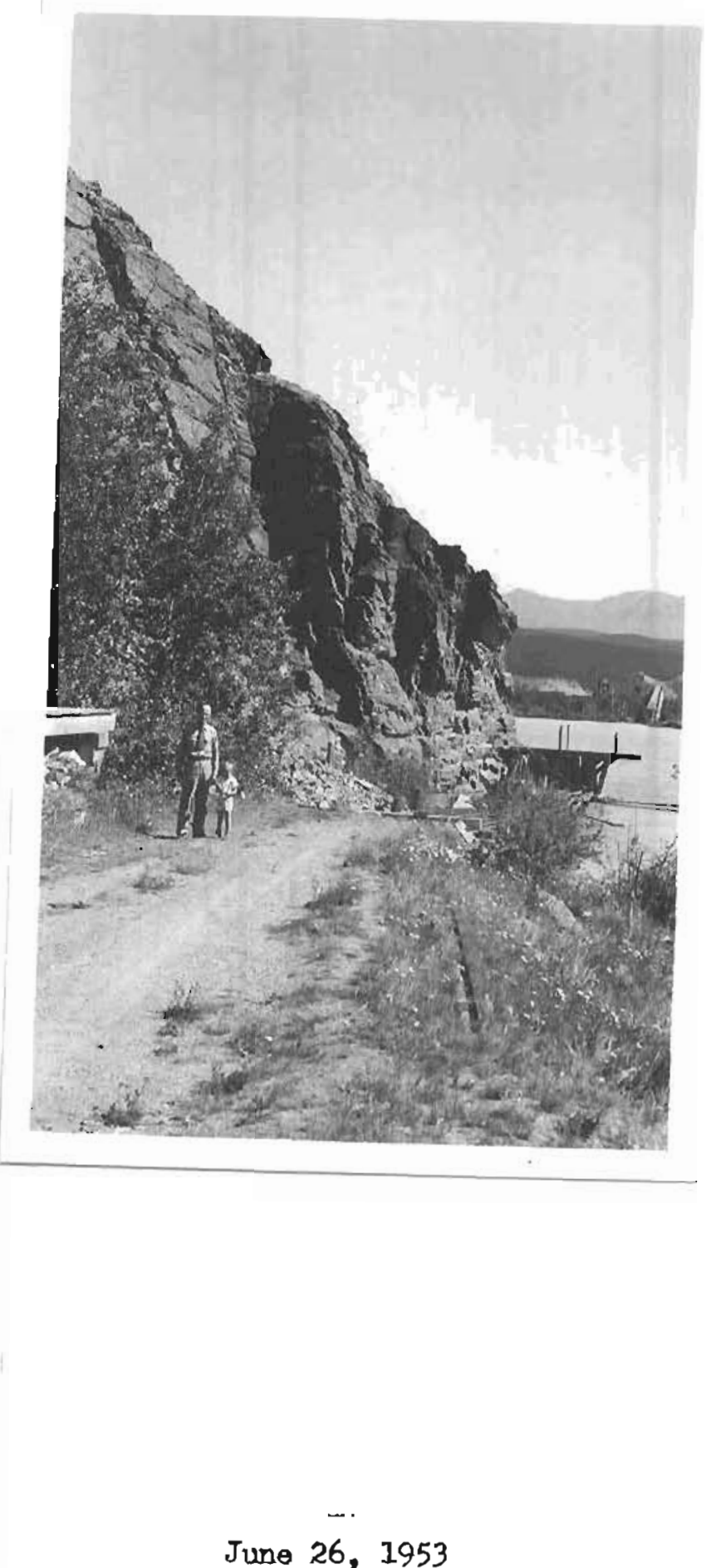

Liberty Falls, Chitina Blghway 